\title{
Persepsi terhadap Perempuan Bertato (Analisis Deskriptif Remaja di Banda Aceh)
}

\author{
Nathasia $^{1}$, Gregorius Genep Sukendro ${ }^{2 *}$ \\ ${ }^{1}$ Fakultas Ilmu Komunikasi, Universitas Tarumanagara, Jakarta \\ Email: nathasiaa01@gmail.com \\ ${ }^{2}$ Fakultas Ilmu Komunikasi, Universitas Tarumanagara, Jakarta* \\ Email: geneps@fikom.untar.ac.id
}

Masuk tanggal : 15-12-2021, revisi tanggal : 06-01-2022, diterima untuk diterbitkan tanggal : 06-01-2022

\begin{abstract}
Nowadays, the point of view of tattoos has begun to change, tattoos are starting to become a popular culture that is a trend among young people, not only for men, but also for women. especially teenagers in Banda Aceh. Indonesia, who have a negative perception of the phenomenon of women with tattoos that occur. There are 3 aspects that can influence a person's perception, namely cognitive aspects, affective aspects and conative aspects. The theory used is the theory of perception. This research will use phenomenology methods. The purpose of this study was to find out and understand the perspective of Banda Aceh teenagers towards women with tattoos. The results of the study show how teenagers in Banda Aceh explained their perceptions of women with tattoos and the aspects they believed could influence the formation of perceptions. Of the three aspects of perception, the affective aspect is the most prominent aspect in the formation of teenagers' perceptions in Banda Aceh. Affective aspects that influence the perception of teenagers in Banda Aceh are based on cultural values, and the existing value system.
\end{abstract}

Keywords: Banda Aceh teenagers' perception, perception theory, tattooed women

\begin{abstract}
Abstrak
Pada masa kini, pandangan terhadap tato sudah mulai berubah, tato mulai menjadi sebuah budaya populer yang tren di kalangan muda, bukan hanya untuk laki-laki saja, namun juga bagi kalangan perempuan, Namun tidak dapat dipungkiri bahwa saat ini, masih ada masyarakat di daerah khususnya remaja di Banda Aceh, Indonesia yang memiliki persepsi negatif terhadap fenomena perempuan bertato yang terjadi. Terdapat tiga aspek yang dapat mempengaruhi persepsi seseorang yaitu aspek kognitif, aspek afektif dan aspek konatif. Teori yang dipakai yakni Teori Persepsi. Metode penelitian ini adalah fenomenologi. Adapun tujuan dari penelitian ini adalah untuk mengetahui dan mengerti pandangan remaja Banda Aceh terhadap perempuan bertato. Hasil penelitian yakni, remaja di Banda Aceh menjelaskan persepsi mereka terhadap perempuan bertato serta aspek-aspek yang dipercayai dapat mempengaruhi pembentukan persepsi. Dari tiga aspek persepsi tersebut, aspek afektif merupakan aspek yang paling menonjol dalam pembentukan persepsi remaja di Banda Aceh. Aspek afektif yang mempengaruhi persepsi remaja di Banda Aceh didasari oleh nilai-nilai kebudayaan, dan sistem nilai yang ada.
\end{abstract}

Kata Kunci: perempuan bertato, persepsi remaja Banda Aceh, teori persepsi

\section{Pendahuluan}

Ada berbagai macam cara dan media untuk berekspresi dan bereksperimen, salah satu media unik yang digunakan adalah tubuh. Tubuh, bagi beberapa orang 
merupakan media yang tepat untuk menuangkan seni ekspresi diri seperti dengan melakukan aktivitas tato. Kata "tato" berasal dari bahasa Tahiti yaitu "tatu" yang berarti menandakan sesuatu. Tato adalah suatu bentuk dekoratif yang bersifat permanen dan melekat pada kulit tubuh (Anggelina dan Jalil, 2015).

Tato memiliki sejarah yang sangat panjang dan juga nilai yang berbeda-beda. Menurut penelitian Ady Rosa mengenai eksistensi tato Mentawai, selama ini, diyakini bahwa tato tertua ditemukan di Mesir sekitar tahun 1300 SM namun, dari penelitian yang dilakukannya diketahui bahwa tato Mentawai telah ada sejak 1500 tahun sampai 500 tahun sebelum Masehi, yang berarti bisa dikatakan bahwa tato Mentawai merupakan tato tertua di dunia.

Menurut catatan penelitian Ady Rosa, tato pada orang Mentawai merupakan suatu identitas yang membedakan antara klan satu dengan yang lainnya. Selain itu, tato bagi orang Mentawai merupakan tanda pancaran roh dari kehidupan mereka. (Rosa dalam Sasqia, dkk., 2020). Selain suku Mentawai, penggunaan tato juga digunakan pada Suku Dayak. Bagi orang-orang Dayak, pembuatan tato merupakan suatu budaya yang berkaitan dengan kesenian, ibadat dan sebagai penanda status sosial. Mereka juga percaya bahwa tato yang ada di tubuh dapat menyelamatkan diri dan menangkal pengaruh jahat.

Pandangan terhadap tato di Indonesia mulai menjadi menakutkan sejak adanya kasus penembakan misterius yang terjadi di tahun 1982-1985. Saat itu, pemerintah Orde Baru sedang menggalakkan operasi pemberantasan kejahatan di beberapa wilayah di Indonesia. Operasi itu dilakukan karena masyarakat pada saat itu sangat resah dengan ulah para preman. Kebanyakan korban dari Penembakan Misterius (petrus) adalah orang-orang yang memiliki tato di tubuhnya. Beberapa korban ditemukan tewas di pinggir jalan, sawah dengan mengenaskan. (Hasyyati, 2017).

Sejak saat itu, pandangan terhadap tato pun mulai melekat dengan bentukbentuk kriminalitas, karena dilihat dari kenyataannya banyak sekali penjahat ataupun orang-orang kriminal yang bertato, preman bertato, gangster bertato, pencuri bertato. Pandangan terhadap perempuan bertato juga cenderung mengarah ke tipikal perempuan eksibisionis, karena kaum hawa yang bertato kerap menggunakan pakaian yang cenderung memperlihatkan tato mereka (Dewi, 2013).

Setelah runtuhnya rezim Orde Baru dan kemudian beralih ke era reformasi, di awal tahun 2000-an, dikarenakan kebebasan berekspresi di segala bidang, tato mulai kembali digemari oleh banyak orang dan menjadi salah satu budaya populer, walaupun masih ada kesan negatif yang melekat pada masyarakat.

Di Indonesia, tato sekarang dikenal sebagai sebuah bentuk seni dan juga tren atau gaya masa kini yang pemakainya cenderung populer (Sanjaya dan Sukendro, 2019). Tato pada masa ini telah menjadi salah satu tren yang menjadi salah satu gaya hidup dari masyarakat perkotaan terbukti dari adanya selebriti-selebriti maupun publik figur yang menghiasi tubuhnya dengan tato yang kemudian juga mempengaruhi remaja yang mengidolakan publik figur tersebut untuk mengikuti gaya hidup yang sama dengan idolanya (Mulyana, 2014). Beberapa perempuan terkenal di Indonesia yang menggunakan tato, antara lain Susi Pudjiastuti yang merupakan Menteri Kelautan dan Perikanan di Indonesia, Widi Vierratale, Chef Renata Moeloek, Sophia Latjuba, Aurelie Moeremans dan lain-lain. Namun pada saat ini, perempuan yang menggunakan tato masih kerap dihubungkan dengan hal-hal yang bersifat negatif. Stereotip perempuan yang bertato masih sangat buruk. Kebanyakan orang menilai perempuan yang memiliki tato di tubuhnya identik dengan hal-hal negatif seperti sangar, menyeramkan, preman, perempuan nakal, liar dan lain-lain. 
Tato bagi beberapa suku di Indonesia masih memiliki makna yang spesial seperti bagi laki-laki Dayak. Tato yang digunakan biasanya merupakan motif yang melambangkan kejantanan, keberhasilan dalam perang, dan identitas kesukuan, sedangkan pada perempuan Dayak, tato memiliki fungsi untuk mempercantik diri. Tradisi tato pada kaum hawa dianggap sebagai lambang keindahan dan harga diri, bagi orang-orang Dayak, perempuan bertato dianggap lebih tinggi derajatnya daripada yang tidak bertato (Maunati dalam Kaffah dan Sudiantara, 2015).

Pada masyarakat suku Belu di pulau Timor, kaum perempuan bertato merupakan simbol dari kecantikan dan medium daya tarik lawan. Pada masyarakat Sumba, perempuan menggambar tato dengan warna hitam pekat di pergelangan kaki mereka untuk menandakan bahwa mereka sudah mempunyai pasangan tetap. (Dewi, 2013).

Remaja merupakan masa perubahan dari anak-anak menjadi dewasa, perubahan ini meliputi perubahan psikologis, biologis dan perubahan sosial (Sofia dan Adiyanti, 2013). Masa remaja dimulai sekitar pada usia 12 tahun dan berakhir pada usia 18 hingga 20 tahun (King, 2012). Masa remaja merupakan titik puncak emosionalitas, terjadinya perubahan emosi yang tinggi yang salah satunya disebabkan oleh pertumbuhan fisik remaja terutama organ-organ seksual. Pertumbuhan fisik tersebut bisa mempengaruhi berkembangnya emosi atau perasaan-perasaan dan dorongan-dorongan baru yang dialami sebelumnya seperti perasaan cinta, rindu dan keinginan untuk berkenalan lebih intim dengan lawan jenisnya (Yusuf, 2012). Remaja pada saat ini merupakan generasi yang sangat diharapkan dapat meneruskan masa depan, pandangan para remaja pada saat ini sangat penting untuk perkembangan pengetahuan.

Masyarakat Aceh memiliki adat dan budaya yang sangat patriarki dan juga syariah. Perempuan Aceh terikat oleh nilai-nilai agama, budaya yang melekat dalam masyarakat yang tradisional. Anggapan seperti perempuan tidak harus menjunjung tinggi pendidikan, perempuan harus bisa memasak, melahirkan masih sangat kental bagi masyarakat Aceh. Menjadi perempuan yang lemah lembut, pandai merawat diri, memiliki kulit yang mulus dan bersih, bisa memasak dan hormat merupakan ciri khas yang ideal untuk perempuan Aceh, mengakibatkan banyak perempuan Aceh yang kesulitan untuk mengekspresikan dirinya, terutama dalam hal tato. Orang Aceh cenderung memiliki pandangan yang negatif terhadap tato, kebanyakan dari mereka memiliki anggapan bahwa tato adalah hal yang tidak pantas apalagi pengguna tato adalah perempuan (Kiram, 2020).

Banda Aceh merupakan wilayah pelaksanaan syariat Islam dan menurut pandangan Islam, tato adalah suatu hal yang dilarang. Hal itu mempengaruhi pandangan masyarakat Aceh terhadap pengguna tato. Berdasarkan observasi awal, pengguna tato di Kota Banda Aceh harus menutupi tatonya di tempat keramaian untuk menghindari pandangan negatif dari masyarakat. Para pengguna tato menggunakan tato di bagian tubuh yang dapat disembunyikan dengan pakaian. Mereka tidak menampakkan tato yang dapat dilihat oleh orang lain. Kebanyakan para pengguna tato di Banda Aceh masih tidak nyaman dengan pandangan orang sekitar (Irawan, 2016).

Tato menampilkan kesan yang tidak lazim di kota Banda Aceh khususnya pengguna tato membuat mereka resah jika tato itu tampak oleh kasat mata masyarakat di Aceh. masyarakat Banda Aceh yang sangat kental akan syariat Islamnya memberikan pandangan yang tajam bagi pengguna tato (Irawan, 2016). 
Rumusan masalah dalam penelitian ini yaitu bagaimana pandangan remaja Banda Aceh terhadap perempuan bertato. Penelitian ini bertujuan untuk mengetahui berbagai pandangan remaja di Banda Aceh terhadap fenomena perempuan bertato.

\section{Metode Penelitian}

Jenis penelitian ini adalah kualitatif deskriptif, yaitu jenis penelitian yang menjelaskan atau menggambarkan suatu fenomena, dalam hal ini persepsi remaja Banda Aceh terhadap perempuan bertato. Adapun pendekatan yang digunakan dalam penelitian ini adalah pendekatan fenomenologi. Fokus umum penelitian ini adalah untuk meneliti esensi atau struktur pengalaman ke dalam kesadaran manusia (Tuffour dalam Hellaudin, 2018).

Penelitian ini melekat pada fenomena yang terjadi di lingkungan sosial yang ada di kota Banda Aceh, yaitu di Banda Aceh, jarang sekali terdapat orang yang menggunakan tato ditubuhnya, dan peneliti yakin dengan menggunakan pendekatan fenomenologi dan pengumpulan data dengan menggunakan teknik wawancara secara mendalam maka kita dapat lebih mengerti perspektif para informan sebagai perwakilan remaja di Banda Aceh.

Wawancara dilakukan bersama delapan informan yang terdiri dari empat remaja perempuan dan empat remaja laki-laki yang memiliki latar belakang keluarga, suku, dan agama yang berbeda, terdiri dari: 2 orang dengan suku Tionghua, 2 orang suku Batak, 2 orang suku Jawa, 2 orang suku Aceh. Para informan dipilih berdasarkan pengalaman dalam pergaulan di kota Banda Aceh, hubungan dengan keluarga, teman yang memiliki tato di tubuh, dan peneliti percaya bahwa para informan dapat mewakili perspektif remaja di kota Banda Aceh, karena dipercaya bahwa para informan sudah menetap lama di kota Banda Aceh dan mengerti setiap hukum dan aturan yang berlaku di kota Banda Aceh.

Selain itu, dokumentasi dengan para informan dan juga studi kepustakaan juga dilakukan. Teknik analisis data pada penelitian ini dimulai dengan mengumpulkan data dari hasil wawancara secara mendalam, dokumentasi dan studi kepustakaan kemudian data akan disusun secara sistematis sehingga dapat memudahkan proses penarikan kesimpulan dan lebih mudah dipahami, kemudian peneliti akan menghubungkan dan menganalisis data dengan apa yang diteliti.

\section{Hasil Temuan dan Diskusi}

Berdasarkan hasil wawancara peneliti dengan delapan orang informan, Elysia, Cindy, Indarhe, Nafisha, Hariyo, Timothy, Jefanya, dan Fernanda, menunjukkan bahwa persepsi remaja di Banda Aceh ini bisa saja menuju ke sisi yang lebih mendukung fenomena perempuan bertato. Namun remaja di Banda Aceh ini mengaku bahwa ada beberapa hal yang membatasi diri mereka untuk menjadi suportif terhadap fenomena perempuan bertato. Hal tersebut adalah adanya Syariat Islam yaitu hukum Islam yang berlaku di Aceh, pergaulan dengan lingkungan sosialnya, dan juga didikan yang telah ditanamkan oleh keluarga.

Selain itu, terdapat individu yang mendukung fenomena perempuan bertato, Individu tersebut mengaku bahwa persepsi tersebut dilatarbelakangi oleh didikan keluarganya, dan juga paparan media sosial. Hal tersebut sesuai dengan salah satu teori yang telah dipaparkan sebelumnya yaitu mengenai latar belakang terbentuknya persepsi. Persepsi individu umumnya dibentuk dan dipengaruhi latar belakang seseorang seperti pengalaman, asumsi, keyakinan, nilai dan kondisi tertentu (Emerson, 
Nathasia, Gregorius Genep Sukendro: Persepsi terhadap Perempuan Bertato (Analisis Deskriptif Remaja di Banda Aceh)

dalam Liliweri, 2015). Inilah yang menyebabkan adanya perbedaan persepsi pada setiap orang. Persepsi terkadang menjadi tidak objektif karena sangat bergantung dengan besarnya keyakinan, asumsi, nilai tertentu yang diimplementasikan melalui perilaku.

Ada beberapa aspek dalam persepsi yaitu aspek kognitif, aspek afektif, dan aspek konatif (Walgito dalam Nadiani, 2015). Aspek kognitif tersusun atas dasar pengetahuan atau informasi yang dimiliki seseorang tentang objek. Berkaitan dengan pikiran seseorang apa yang ada dalam pikiran konsumen. Kognitif bersifat rasional, masuk akal. Pernyataan tersebut sesuai dengan hasil penelitian ini, yakni terdapat informan yang menjelaskan bahwa dirinya merasa sangat tidak masuk akal, apabila ia memiliki kesan pertama negatif terhadap perempuan yang bertato.

Menurut informan Timothy, itu merupakan hal yang tidak rasional apabila Ia menghakimi baik buruknya seseorang melalui penampilan fisiknya saja. Menurutnya, setiap orang memiliki alasan tersendiri dalam memutuskan untuk menggunakan tato pada tubuhnya. Pernyataan tersebut juga didukung oleh pendapat dari Cindy sebagai informan. Ia menjelaskan bahwa itu merupakan hal yang tidak masuk akal apabila Ia memandang perempuan bertato ke arah yang negatif, karena menurutnya, perempuan yang tidak memiliki tato di tubuhnya juga dapat melakukan hal-hal buruk dan jahat. Cindy juga menjelaskan bahwa penampilan fisik tidak menjamin baik dan buruknya orang.

Aspek afektif merupakan komponen yang berhubungan dengan rasa senang dan rasa tidak senang, jadi sifatnya evaluatif yang berhubungan erat dengan nilai-nilai kebudayaan atau sistem nilai yang dimilikinya. Berkaitan dengan perasaan, bersifat emosional. Wujudnya bisa berupa perasaan senang, sedih, ceria dan gembira. Hasil penelitian ini membuktikan bahwa adanya keselarasan aspek afektif dengan pendapat para informan. Semua informan menjelaskan secara detail dari alasan dari persepsi mereka. Elysia sebagai salah satu informan menjelaskan bahwa alasan dari pendapatnya didasari oleh didikan keluarganya, Ia memiliki seorang Ibu yang mempunyai tato di tubuhnya, dan hal tersebut membentuk pola pikir Elysia sebagai seseorang yang suportif terhadap fenomena perempuan bertato.

Hariyo yang juga merupakan informan bersuku Tionghoa memiliki persepsi yang tidak mendukung perempuan bertato percaya bahwa persepsi yang ia berikan disebabkan oleh didikan dari kedua orang tuanya. Selain itu, ada informan yang bernama Fernanda, ia menanggapi fenomena perempuan bertato sebagai suatu hal yang aneh dan tidak biasa, karena ia sudah lahir, tumbuh dan menetap di Aceh dan jarang melihat ada perempuan yang bertato di sekitar kota Banda Aceh. Ia juga menjelaskan bahwa hal tersebut dikarenakan syariat Islam yang berlaku di Aceh.

Informan bernama Jefanya juga menjelaskan bagaimana pergaulannya dengan masyarakat setempat, didikan keluarga dan juga syariat Islam yang berlaku di Aceh membentuk pola pikirnya. Jefanya menjelaskan bahwa walaupun ia non-muslim tetapi ia menetap di kota yang menerapkan syariat Islam, sehingga ia harus mengikuti normanorma, hukum, kebiasaan dan juga budaya yang berlaku di Banda Aceh yang juga kurang mendukung fenomena perempuan bertato. Pernyataan tersebut juga didukung oleh salah satu informan bernama Nafisha yang merupakan seorang remaja bersuku Aceh dan beragama Islam di Banda Aceh. Kayla menjelaskan bahwa dalam ajaran agama Islam, tato merupakan hal yang haram, dikarenakan tato di tubuh menyebabkan air wudhu tidak dapat masuk melalui kulit.

Persepsi para informan kemudian didukung dengan adanya teori mengenai nilai-nilai dan budaya yang ada di Aceh. Aceh memiliki budaya yang menarik dan 
luas, nilai-nilai budaya dan agama Islam di Aceh sudah membentuk kesatuan. Terdapat pepatah bagi masyarakat Aceh atau biasa disebut sebagai hadith maja "Hukom ngon adat lagei zat ngon Sifeut". Yang berarti, hukum agama Islam dan hukum adat merupakan suatu kesatuan yang tidak dapat diubah dan tidak dapat dipisahkan (Arifin, 2016).

Di Aceh, budaya dan adat tidak lain adalah norma dan nilai agama itu sendiri. Antara budaya dan agama telah berinteraksi dan berasimilasi secara harmonis dalam masyarakat Aceh sepanjang ratusan tahun. Bentuk konkrit adat dan budaya dalam kehidupan masyarakat Aceh tidak hanya teraplikasi dalam bidang sosial, ekonomi maupun politik, tetapi juga dalam bidang hukum. Realitas masyarakat Aceh dapat disimpulkan sebagai totalitas dari ajaran agama, maka Islam menjadi pandangan hidup (way of life). Pandangan hidup inilah yang mempengaruhi seluruh aktivitas masyarakat termasuk budaya. Pandangan hidup seseorang akan mempengaruhi cara berpikir, cara berperilaku, dan cara berinteraksi dengan sesama manusia, kesemuanya merupakan bagian dari budaya (Kasim dan Nurdin, 2015).

"Adat meukoh reubong, hukom meukah purieh. Adat jeut beurang hoe ta kieh" (Adat bagaikan memotong bambu tua, sekali potong tak akan tumbuh lagi. Adat boleh dikesampingkan, tetapi hukum tak mudah dikiaskan begitu saja). "Hukom meunyoe hana adat tabeue, adat menyoe hana hukom bateue" (Hukum tanpa adat, hambar, adat tanpa hukum batal). Pepatah Aceh di atas menjelaskan suatu pengertian bagaimana persepsi masyarakat Aceh dalam menempatkan posisi Agama (Islam) dan adat. Adat merupakan seperangkat nilai, norma kehidupan masyarakat. Sebagai tata kelakuan, adat merupakan kaedah-kaedah normatif yang diakui dan ditaati oleh warga masyarakat yang bersangkutan.

Aspek konatif merupakan kesiapan seseorang untuk bertingkah laku yang berhubungan dengan objek sikapnya. Berkaitan dengan tindakan. Wujudnya adalah tindakan seseorang. Pernyataan ini didukung dengan penjelasan dari para informan. Seorang informan menjelaskan bahwa ia akan mendukung apabila saudara perempuannya membuat tato di tubuhnya, dan akan membantu memilih desain tato yang bagus. Selain reaksi suportif, terdapat informan yang tidak akan mendukung saudara perempuannya untuk membuat tato dengan cara mengingatkan saudaranya, karena menurutnya tato di Banda Aceh masih merupakan hal yang tabu dan dengan berani memiliki tato di tubuh, maka orang tersebut sudah harus siap menerima hujatan dan juga hinaan yang akan dilontarkan oleh masyarakat setempat. Informan lain juga menjelaskan bahwa merupakan suatu kewajiban dalam agama Islam untuk selalu mengingatkan sesamanya, sehingga ia akan memilih untuk mengingatkan saudaranya untuk tidak membuat tato di tubuhnya.

\section{Simpulan}

Remaja di Banda Aceh memiliki dua persepsi mengenai perempuan bertato yaitu persepsi secara umum (terlepas dari hukum syariat Islam dan lingkungan sosial) dan persepsi sebagai seorang yang tinggal dan menetap di kota Banda Aceh. Persepsi individu secara umum lebih mengarah kepada sisi suportif atau pro terhadap fenomena perempuan bertato karena individu menganggap bahwa tato sebagai suatu bentuk seni, media mengekspresikan diri dan hal-hal positif lainnya. Sedangkan persepsi individu sebagai masyarakat di kota Banda Aceh yang harus mengikuti hukum syariat Islam, pergaulan dan budaya setempat, maka individu tidak akan mendukung fenomena tersebut, karena menurut individu, perempuan yang bertato di kota Banda Aceh 
Nathasia, Gregorius Genep Sukendro: Persepsi terhadap Perempuan Bertato (Analisis Deskriptif Remaja di Banda Aceh)

merupakan hal yang tidak wajar akan menimbulkan hujatan dan hinaan serta pandangan yang buruk.

Ada beberapa aspek yang mendukung pembentukan persepsi remaja yang ada di Banda Aceh dalam menanggapi fenomena perempuan bertato yaitu aspek kognitif yang merupakan pemikiran secara rasional dari para individu, aspek afektif yang dibentuk dari perasaan, nilai-nilai kebudayaan dan sistem nilai yang dimiliki setiap individu, contoh aspek afektif dalam penelitian ini adalah syariat Islam yang berlaku di Aceh, didikan dari keluarga, pergaulan dengan lingkungan sosial, dan pengaruh sosial media, selain itu juga ada aspek konatif yang merupakan tindakan individu terhadap fenomena yang terjadi.

Aceh merupakan satu-satunya provinsi di Indonesia yang menerapkan hukum syariat Islam, dalam ajaran agama Islam menjelaskan bahwa tato adalah haram, dan hal tersebut membentuk pola pikir masyarakat Aceh yang menganggap bahwa orang yang memiliki tato di tubuhnya terutama perempuan merupakan hal yang tabu dan tidak baik. Pengaruh lainnya berasal dari didikan keluarga, keluarga yang memiliki pola pikir lebih terbuka akan mempengaruhi persepsi individu menjadi lebih suportif dan begitu pula sebaliknya, keluarga yang memiliki pola pikir yang lebih tertutup dan masih kental dengan budaya dan adat, akan mempengaruhi persepsi individu menjadi lebih tidak suportif terhadap fenomena perempuan bertato. Selanjutnya persepsi yang dipengaruhi oleh pergaulan dari lingkungan sosial.

Individu yang memiliki lingkaran pertemanan yang luas akan memberikan persepsi yang netral dan positif terhadap fenomena yang terjadi, sedangkan individu yang memiliki lingkup pertemanan dengan masyarakat suku Aceh dan menetap di Banda Aceh akan memiliki persepsi yang kurang suportif terhadap fenomena yang ada. Media sosial pada saat ini juga sangat mempengaruhi pola pikir dan juga persepsi remaja yang ada di Banda Aceh, individu yang sering terpapar media sosial seperti Instagram, Twitter dan lain-lain akan lebih terbiasa dan menganggap perempuan bertato adalah suatu hal yang normal dan wajar, individu yang kurang terpapar media sosial akan beranggapan bahwa perempuan bertato merupakan hal yang tabu dan tidak wajar. Berdasarkan temuan dan pembahasan penelitian, dapat disimpulkan bahwa kebanyakan remaja di Banda Aceh akan lebih memilih menghimbau saudara/teman perempuannya untuk tidak membuat tato di tubuhnya dikarenakan faktor norma, hukum, adat, agama yang berlaku di Banda Aceh.

\section{Ucapan Terima Kasih}

Peneliti mengucapkan terima kasih yang sebesar-besarnya kepada Fakultas Ilmu Komunikasi Universitas Tarumanagara, narasumber serta semua pihak yang turut membantu peneliti sehingga penelitian ini dapat diselesaikan.

\section{Daftar Pustaka}

Anggelina, L. J. H., \& Jalil, H. A. (2015). Tato Dalam Kehidupan Remaja (Studi Kasus Remaja Pengguna Tato Di Kota Pekanbaru). Fakultas Ilmu Sosial dan Ilmu Politik.

Arifin, M. (2016). Islam Dan Akulturasi Budaya Lokal di Aceh (Studi Terhadap Ritual Rah Ulei Di Kuburan Dalam Masyarakat Pidie Aceh). Jurnal Ilmiah Islam Futura. 15(2). 253-258. Asyi, A. Q. A. (2020). The History of Aceh Mengenal Asal Usul Nama, Bahasa, dan Orang Aceh. Banda Aceh: Yayasan PeNA. 
Hasyyati, A. (2017). Peristiwa Penembakan Misterius Di Jakarta 1982-1985. Skripsi. Fakultas Ilmu Budaya. Universitas Padjajaran Jatinangor.

Hellaudin, H. (2018). Mengenal Lebih Dekat dengan Pendekatan Fenomenologi: Sebuah Penelitian Kualitatif. UIN Sultan Maulana Hasanuddin Banten. 6-7.

Irawan, W. (2016). Makna Simbolik Di Kalangan Pengguna Tato di Kota Banda Aceh (Analisis Semiotika). Skripsi. Fakultas Ilmu Sosial dan Ilmu Politik. Universitas Syiah Kuala: Banda Aceh

Ismawardi, I. (2018). Syariat Islam Dalam Lingkup Keberagaman Masyarakat Aceh. Bidayah: Studi Ilmu-Ilmu Keislaman. 9(2). 166-170.

Kiram, M. Z. (2020). Pendidikan Berbasis Gender Dalam Keluarga Masyarakat Aceh. Community. 6(2). 184-187.

Lestari, Y. I., \& Fellasari, F. (2016). Hubungan Antara Pola Asuh Orangtua Dengan Kematangan Emosi Remaja. Jurnal Psikologi. 12(2). 84-85.

Nadiani, H. F. S. (2015). Hubungan Antara Persepsi Santri Nahun Terhadap Figur Kiai Dengan Kelekatan Aman Di Perguruan Islam Pondok Tremas Pacitan. Skripsi. Fakultas Psikologi. Universitas Islam Negeri Maulana Malik Ibrahim: Malang. ntb.bkkbn.go.id. (Oktober, 2019). MENGENAL REMAJA GENERASI Z (Dalam Rangka memperingati Hari Remaja Internasional).

Pemerintah Kota Banda Aceh. (2021). Agama.

Sanjaya, R., \& Sukendro, G. G. (2019). Ideologi dan Komunikasi Bob Sick Terkait Tato di Sekujur Tubuhnya Melalui Profesi. Koneksi. 3(1). 1-4.

Sugiyono. (2020). Metode Penelitian Kuantitatif Kualitatif dan R\&D. Bandung: Alfabeta.

Yasim, C. R., \& Candraningrum, D. A. (2019). Makna Citra Diri Perempuan Bertato Yang Berhijab. Jurnal Untar. 3(1). 82-83. 